\title{
The Future of Brand Personality: Systematic Review and Research Agenda
}

\author{
Daniel Carvalho ${ }^{1}$, Gisela Demo², Fernanda Scussel ${ }^{3}$
}

\begin{abstract}
${ }^{1}$ http://orcid.org/0000-0002-5307-7680 / Universidade de Brasília (UnB), Brasil
${ }^{2}$ http://orcid.org/0000-0003-1864-0471 / Universidade de Brasília (UnB), Brasil

${ }^{3}$ http://orcid.org/0000-0001-7953-6710 / Universidade de Brasília (UnB), Brasil
\end{abstract}

The main purpose of this paper was to report a literature review that synthesized and organized the current knowledge on brand personality, with the goal of drawing a research agenda on the construct, setting directions for future investigations. We combined a systematic review with bibliometric analysis to evaluate 351 articles about brand personality published between 2015 and 2019. The current research on brand personality has a background in psychology studies, using the appropriation of personality construct to understand the functioning of consumers' minds. The current literature encompasses six research tracks, namely: 1) brand-related outcomes, 2) consumer-related outcomes, 3) scale development, 4) experiments and metrics, 5) tourism, and 6) conceptualizations. As a research agenda, we propose the development of theorizations on brand personality and investigations about its antecedents, the context of investigation, the stability of the construct and the brand personality in the context of social media.

Keywords: brand personality, systematic review, bibliometric analysis.

O Futuro da Personalidade de Marca: Revisão Sistemática e Agenda de Pesquisa

Resumo

O objetivo deste artigo foi relatar uma revisão de literatura que sintetizou e organizou o conhecimento atual sobre personalidade de marca, para traçar uma agenda de pesquisa sobre o construto e direcionar futuras investigações. Combinamos uma revisão sistemática com análise bibliométrica para avaliar 351 artigos sobre personalidade de marca publicados entre 2015 e 2019 . As pesquisas atuais sobre personalidade de marca baseiam-se em estudos de psicologia, com a apropriação do construto de personalidade para compreender o funcionamento das mentes dos consumidores. A literatura atual abrange seis linhas de pesquisa, a saber: resultados relacionados à marca, resultados relacionados ao consumidor, desenvolvimento de escala, experimentos e métricas, turismo e conceituações. Como agenda de pesquisa, propomos o desenvolvimento de teorizações sobre a personalidade da marca e investigações sobre seus antecedentes, o contexto de investigação, a estabilidade do construto e a personalidade da marca no contexto das mídias sociais.

Palavras-chave: personalidade da marca, revisão sistemática, análise bibliométrica.
E1 Futuro de la Personalidad de la Marca: Revisión Sistemática y Agenda de Investigación

Resumen

El objetivo principal de este artículo es presentar una revisión de literatura que sintetizó y organizó el conocimiento actual sobre la personalidad de la marca, cuyo objetivo es planear una agenda de investigación sobre el constructo, marcando rumbos para futuras investigaciones. Programamos una revisión sistemática con análisis bibliométrico para evaluar 351 artículos sobre personalidad de marca publicados entre 2015 y 2019. La investigación actual sobre personalidad de marca se basa en estudios de psicología, con la apropiación del constructo de personalidad para comprender el funcionamiento de las mentes de los consumidores. La literatura actual abarca seis lineas de investigación, a saber: 1) resultados relacionados con la marca, 2) resultados relacionados con el consumidor, 3) desarrollo de escalas, 4) experimentos y métricas, 5) turismo y 6) conceptualizaciones. Como agenda de investigación, proponemos el desarrollo de teorizaciones sobre personalidad de la marca e investigaciones sobre sus antecedentes, el contexto de investigación, la estabilidad del constructo y la personalidad de la marca en el contexto de las redes sociales.

Palabras clave: personalidad de marca, revisión sistemática, análisis bibliométrico. 
Brand personality is "the set of human characteristics associated with a brand" (Aaker, 1997, p. 347), helping consumers to create positive associations with a brand, beyond its utilitarian dimension, serving a symbolic function (Keller, 1993). As proposed by Aaker (1997), this association is motivated by marketing and branding efforts through techniques like anthropomorphization, personification and the creation of customers' imagery, when customers start to imbue a brand with personality traits - for example, Coca-Cola is cool and real, which will differentiate the brand from the competition.

With roots in psychology studies and the appropriation of this literature to develop consumer behavior investigations, the concept of brand personality has soon arisen as a central element in marketing works (Giroux, Pons, \& Maltese, 2017; Scussel \& Demo, 2016).

In the 1950's, marketing literature recognized the power of personality traits in describing companies, products and brands, and, in the 1980's, brand personality gained consistency as a research stream, when scholars suggested the use of personality and its measurement instruments in brand personality studies. However, it was only during the 1990's, with the seminal work of Jennifer Aaker (1997), that brand personality was set as a unique construct, conceptualized and operationalized to the proper measurement of the personality traits of brands. According to Aaker (1997), customers perceive brand personality as soon as they communicate with a brand, in any point of interaction, moment in which they imagine what kind of person the brand would be. This is valid in market context due to the fact consumers attribute human personality traits to brands in order to identify and differentiate them.

The background of brand personality in psychology studies has had a consequence over time, giving rise to three main areas of research (Azoulay, 2005; Scussel \& Demo, 2016). The first group explores the congruency between customer and brand personalities and its impact on brand preference (Huang, Mitchell, $\&$ Rosenaum-Elliot, 2012). The second research investigates the relation between brand personality and several marketing variables such as brand strategy (Naresh, 2012); brand positioning (Kim \& Sung, 2013); brand experience (Choi, Ok, \& Hyun, 2017); customer loyalty (Demo et al., 2018) and customer relationship perception (Scussel \& Demo, 2019).

The last research group concerns brand personality measurement. Until the 1990's, there was no scale attending the reliability, validity and generalization criteria to measure brand personality. According to Aaker (1997), early works on brand personality resorted to checklists, photo-sorts and symbolic analogies, followed by the use of human personality measurements. Regardless of the great contribution of human personality scales to the context of brands, they proved to be limited to identify customer perception regarding brand personality (Aaker, 1997). This limitation is attributed to the antecedents of human personality and brand personality, as they differ in the way they are formed: human personality traits arise from the person's behavior, the physical characteristics, attitudes and beliefs; meanwhile, the brand personality traits emerge from any direct or indirect contact a consumer has with a brand (Aaker, 1997). This was the motivations for the author to create the first "reliable, valid, and generalizable scale to measure brand personality" (Aaker, 1997, p. 347), with five dimensions - sincerity, excitement, competence, sophistication and ruggedness.

Aaker's scale (1997) established a theoretical framework for the brand personality construct with reliable and valid measures in the American context (Muniz \& Marchetti, 2012), being the starting point for replication or reconstruction in studies carried out in other countries, considering the role of culture in shaping the way consumers perceive brand personality (Aaker, 1997). The original scale was empirically tested in different countries (Aaker, Benet-Martínez, \& Garolera, 2001; Muniz \& Marchetti, 2012). These works corroborate the hypothesis that brand personality is a context-dependent construct, since it reveals different dimensions in distinct cultures.

From the analysis of the literature that initiated and developed the brand personality body of knowledge, we observe that, despite the relevance of brand personality for academics and marketing practioners, the construct holds controversies, especially regarding its theoretical foundations and the applicability of its dimensions across different contexts (Freling, Crosno, \& Henard, 2011). This debate has turned brand personality into a topic of growing interest for both psychology and marketing scholars because of its fragmented literature and the lack of definition and operationalization for the construct, requiring constant efforts in understanding the dynamics of this scientific field (Radler, 2017; Scussel \& Demo, 2016).

On that basis, we understand that a literature review on brand personality could be a starting point to summarize and organize the current knowledge on this theme, as well as guiding the efforts of scholars in future investigations. In this regard, literature reviews emerge as a relevant type of study to provide a broader comprehension and summarization of a scientific construct, theme or phenomenon (Tranfield, Denyer, \& Smart, 2003), a paramount condition to the growth and development of the knowledge in a certain field of study (Templier \& Paré, 2015). Literature reviews help to synthesize the literature on widely investigated areas, contributing to theory development, research tracks identification and future perspectives proposition (Okoli \& Schabram, 2010; Snyder, 2019). Lastly, as proposed by Zupic and Carter (2015), mapping the scientific knowledge should be a periodic task, enabling the conduction of future research connected to the current knowledge.

Thus, the purpose of this paper is to report a literature review that synthesized and organizes the current knowledge on brand personality, which will allow us to pursuit its main objective: to draw a research agenda on the construct, setting directions for future investigations.

To address these issues, we explore the intellectual structure of brand personality scientific field, identifying the most influential articles, journals and authors, as well as the most studied content in the area and the emerging topics of interest (Zupic \& Carter, 2015), Second, we use the understanding of the scientific field to generate directions for future research, conforming the main contribution of this paper, following the guidance of Paul and Criado (2020).

\section{Method}

In this paper, we combine the qualitative approach of systematic reviews with the quantitative approach of bibliometric methods to draw the social and intellectual structures of brand personality scientific field of research with the higher purpose of developing a research agenda. Systematic review is a method that helps scholars to understand, organize and summarize data from a specific subject, following a qualitative approach, enabling conclusions on a certain phenomenon (Tranfield, Debyer, \& Smart, 2003). As explained by Zupic and Carter (2015), bibliometric analysis are a useful help in literature reviews since research design, promoting a more transparent and reproducible review process.

Combining the guidelines for systematic reviews (Tranfield 
et al., 2003) and for bibliometric analysis (Zupic \& Carter, 2015), we started our review process with the research design, a phase of research question and scope definition, which has been done in the introduction of this paper. The next stage is conducting the review, being the first step selection of the studies (Tranfield et al., 2003). In this step, Zupic and Carter (2015) explain the need to specify the decisions regarding the databases, the criteria of inclusion and exclusion for the articles and the final sample of papers to be analyzed.

We decided to analyze the most recent developments in brand personality, defining the temporal frame of five years (2015 to 2019). We followed Tranfield et al. (2003) orientation regarding the highest level of scientific evidence, the reason why we selected only peer-reviewed scientific articles from the databases Web of Science and Scopus. Zupic and Carter (2015) recommend the use of the Web of Science database and Scopus, since they are a fertile source of bibliographic data, with a wide coverage of subject categories, an adequate selection for the study of brand personality, a construct investigated for both psychology and marketing scholars (Scussel \& Demo, 2016). Regarding our search strategy, we used the keyword "brand personality", providing us a preliminary sample of 379 articles. We decided to keep all the articles, excluding only the duplicated ones, obtaining a final sample of 351 papers.

The following stage is data extraction (Tranfield et al., 2003), when we must select the appropriate bibliometric software (Zupic $\&$ Carter, 2015). The analysis of the data was made using the software VOSviewer 1.6.11, in order to generate the descriptive analysis about our sample, providing a cartography analysis that enables the identification of the interconnections between the content of articles, enabling the visualization of key research streams and an overview of the structure of the field. We have extracted information regarding year of publication, authors, journal of publication and country of publication. Additionally, we have analyzed the number of citations based on information from Google Scholar in June 2020.

The next stage concerns data synthesis and visualization. We analyzed and interpreted the results from the descriptive analysis generated by the software VOSviewer, along with a content analysis of the title, keywords and abstract of the papers in order to combine the bibliometric analysis with the interpretation from systematic reviews, enabling a broader comprehension of the field
(Paul \& Criado, 2020). Table 1 summarizes the literature review process.

\section{Results and Discussion}

The first findings we present is an analysis of the productiveness of the scientific field dedicated to brand personality. To achieve this result, we created Figure 1, a graph that shows the publications between 2015 and 2019 by the year. This period has produced 351 papers, an average of 70 articles published each year. From 2015 and 2017, we note there is a slightly decrease in the productiveness, followed by a turn in 2018 and a growth trend. The year of 2019 was the most productive year, with 85 works. Therefore, it is plausible to say the interest in the brand personality construct is growing, reinforcing our idea that that understanding brand personality scientific production behavior is paramount to identify what is next and offer direction for future studies.

The 351 articles of our sample were spread in 170 journals and the next step was to perform a citation analysis in order to identify the journals that most influenced the brand personality research, both in number of publications and number of citations. As proposed by Zupic and Carter (2015), citation is a measure of influence and can be used as a method to identify the most relevant works in a scientific field. Based on this, we elaborated in our sample an analysis of the most productive journals (Table 2) and the most cited papers (Table 3), based on the importance to analyze scientific production constantly to understand brand personality because just papers published early in date span would have a chance of influencing work published within your date span.

The Journal of Business Research leads the ranking in both Table 2 and 3, proving to be the most influential journal in the brand personality literature. This journal recognizes the relations between management research and the diverse knowledge areas that sustain business research. In their scope, we found articles relating brand personality to economic factors (Priporas, Stylos, \& Kamenidou, 2019), brand experience (Japutra \& Molinillo, 2019), brand alliances (Kim, Vaidyanathan, Chang, \& Stoel, 2018) and cultural differences (Zabkar, Arslanagic, \& Diamantopoulos, \& Florack, 2017).

The same dynamic is found for the Journal of Brand Management. With a strong focus in brand management and strategy, this journal covers high quality scientific evidence regarding brand

Table 1

Literature Review Process

Systematic Review (Tranfield et al., 2003) a review and preparation of the proposal for the review

Research design: research question definition and selection of the appropriate method for the research question.
Planning the review: identification for the need for

The process of this research

Research question: what is the current panorama on brand personality research, considering the social and intellectual structures of this scientific field, and how can we build a research agenda from this analysis?

Method: qualitative and quantitative analysis of the recent literature on brand personality - systematic review and bibliometric analysis

Databases: Web of Science and Scopus Keywords: "brand personality"

Conducting the review: identification of the research, Compilation of bibliometric data: selection of dataselection of studies and study quality assessment base, search criteria, journal and articles
Inclusion and exclusion criteria: only duplicates were excluded

Final sample: 351 articles

Data extracted: year of publication, authorship, institutional bond of the authors, country of publication, number of citations

Bibliometric software: VOSviewer 1.6.11 and Microsoft Excel

Analysis: citation analysis, co-citation analysis, biblio-

graphic coupling and content analysis 


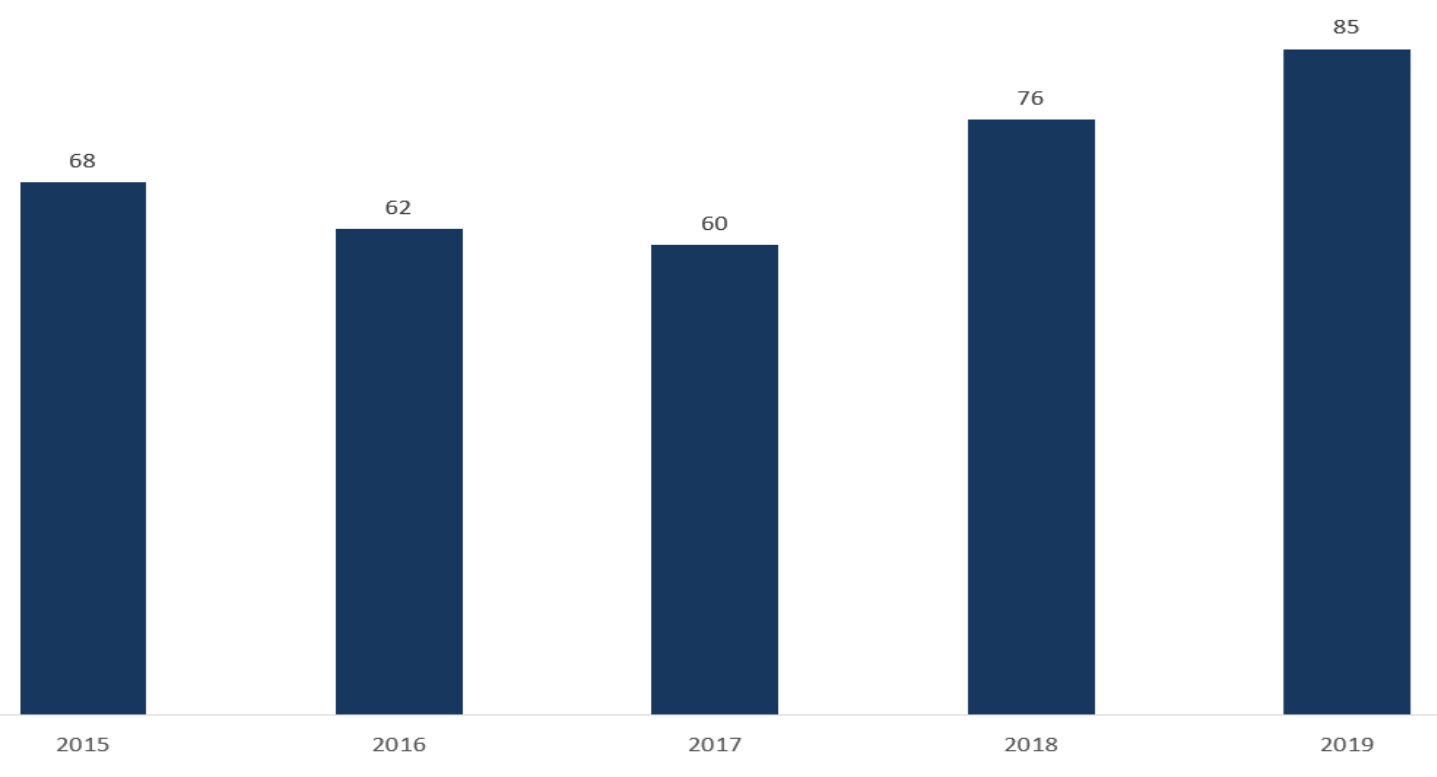

Figure 1. Brand personality studies by year

Table 2

The most productive journals in the brand personality field

\begin{tabular}{|c|c|c|}
\hline Ranking & Journal & Number of papers \\
\hline $1 \mathrm{st}$ & Journal of Business Research & 12 \\
\hline 2nd & Journal of Brand Management & 11 \\
\hline $3 \mathrm{rd}$ & Journal of Product and Brand Management & 10 \\
\hline 4th & $\begin{array}{c}\text { Psychology and Marketing Tourism } \\
\text { Management }\end{array}$ & 8 \\
\hline 5 th & $\begin{array}{c}\text { Asia Pacific Journal of Marketing and } \\
\text { Logistics }\end{array}$ & 7 \\
\hline
\end{tabular}

Table 3

The most cited journals in the brand personality field

\begin{tabular}{ccc}
\hline Ranking & Journal & $\begin{array}{c}\text { Number of } \\
\text { citations }\end{array}$ \\
\hline 1st & Journal of Business Research & 194 \\
\hline 2nd & Psychology \& Marketing & 113 \\
\hline 3 rd & Tourism Management & 110 \\
\hline 4 th & Journal of Product and Brand Management & 89 \\
\hline 5 th & Journal of Brand Management & 83 \\
\hline
\end{tabular}

management, especially branding, context in which we have found relevant works on brand personality. In the Journal of Brand Management, brand personality is seen as a relational construct (Ramadan, 2019), associated to brand equity (Brunett, Confente, \& Kauffman, 2019), brand strategy (Lee \& Trim, 2019) and brand experience (Kim \& Song, 2019).

The Journal of Product and Brand Management also appears in both Tables 2 and 3. Its scope is interdisciplinary, as long as the content of the papers contribute to enhance of branding and product management research. For example, the journal encompasses papers dedicated to brand personality as a relational construct (Hassey, 2019), the role of self-congruity and brand personality on nation brands (Rojas-Méndez, Papadopoulos, \& Alwan, 2015) and the impact of brand personality in brand equity (Su \& Tong, 2015).

The Asia Pacific Journal of Marketing and Logistics, although the fifth most productive journal (Table 1) does not appear in the top five most cited journals (Table 3). This journal if focused, as proposed in their website, in marketing and logistic studies in the Asia Pacific context, signalizing the importance of branding issues for the conceptual and managerial knowledge in this region.
Another interesting finding from the analysis of Tables 1 and 2 is the appearance of journals combining psychology and marketing (Psychology and Marketing Tourism Management and Psychology \& Marketing), revealing a connection between these two disciplines, which we foresee because of the origin of brand personality studies, which is in psychology literature (Aaker, 1997).

Lastly, we must highlight the journals concentrating attention in tourism and hospitality management (Psychology and Marketing Tourism Management and Tourism Management) confirming that brand personality has a relevant impact in this industry (Rather, Hollebeek, \& Islam, 2019; Unurlu \& Uca, 2017).

In the following, we start to investigate the social structure of the brand personality scientific field, as recommended by Zupic and Carter (2015). By performing this type of analysis, researchers can understand the central, peripheral or bridging nations in a field of study, comprehending how the diffusion of knowledge happens. According to the scholars, this type of investigation also helps us to overview the structure of the scientific community. In this perspective, we tracked the journal country in which the articles from our sample were published, presenting the ranking of the countries with the highest number of published articles (Table 4) and the ranking of the countries with the highest number of citations (Table 5).

Table 4

Ranking of the countries that have published the most about brand personality

\begin{tabular}{ccc}
\hline Ranking & Country & Number of papers \\
\hline 1 st & United States & 47 \\
\hline 2nd & India & 22 \\
\hline 3 rd & China & 12 \\
\hline 4 th & Brazil & 10 \\
\hline 5 th & Korea & 10 \\
\hline
\end{tabular}

Our objective with this analysis is to identify the nations with the highest impact in brand personality scientific production. In this sense, the United States lead the ranking in both Tables 4 and 5. We understand this result is a consequence of the seminal article published by Aaker (1997) and its impact on the literature in this field. Besides, brand personality is a construct associated with competitive advantage since it is capable of creating emotional bonds with customers (Giroux et al., 2017) and a starting point for long-term relationships (Fournier, 1998; Scussel \& Demo, 2019), 
Table 5

Ranking of the most cited countries, considering the origin of the articles

\begin{tabular}{ccc}
\hline Ranking & Country & Number of papers \\
\hline 1 st & United States & 430 \\
\hline 2 nd & Korea & 133 \\
\hline 3 rd & Austria & 68 \\
\hline 4 th & India & 65 \\
\hline 5 th & China & 64 \\
\hline
\end{tabular}

following the American perspective of business development through branding strategies (Schwarzkopf, 2009).

India and China are nations that appear in both Tables 4 and 5 and, along with Brazil as the 4th country in number of publications (Table 4), we note the rise of emerging countries from the BRIC as sources of influential research on brand personality. This finding is also a confirmation of the role of branding strategies in increasing market transactions in emerging economies (Omar \& Ensor, 2011), being brand personality a source of competitive advantage to the companies and brands located in such regions as well.

We can also interpret the diversity of nation of origin of the most influential papers (Table 5) by the lens of brand personality as a cultural construct, as the proper analysis of its impact is associated to the cultural aspects of the context of investigation (Aaker, 1997; Muniz \& Marchetti, 2012). Moreover, these findings can be linked to the rise of the interest from tourism and hospitality researchers in brand personality as a useful construct in place branding and destination branding (Nobre, Demo, Scussel, \& Watanabe, 2020), in alignment with the previous discussed findings from Tables 2 and 3.

In the following analysis, we aim to identify and understand the intellectual structure of the brand personality scientific field, since "the intellectual structure of a given discipline addresses the knowledge base of the discipline" (Köseoglu, Okumus, Dogan, \& Law, 2018). This in an important move to estimate the influence of researchers and articles, especially when we consider the area of expertise of the scholars and the content of the most popular works, as they will influence the future of the research in a specific field (Zupic \& Carter, 2015).

Moreover, as Köseoglu et al. (2018) affirm, the development of a research agenda to guide future research requires the assessment of the history of the field, the current research and the analysis of the traditions, dogmas and perceptions. To achieve our purpose of building future directions for brand personality research, we follow the guidance of Zupic and Carter (2015) and Köseoglu et al. (2018), exploring the most productive authors and the most cited studies in the period analyzed in this systematic

Table 6

The most productive researchers

\begin{tabular}{|c|c|c|c|c|}
\hline Number of Papers & Researcher & Institution & Country & Area of Expertise \\
\hline \multirow{4}{*}{5} & Bang Nguyen & $\begin{array}{c}\text { East China University of Science and } \\
\text { Technology }\end{array}$ & China & Marketing Management \\
\hline & Fernanda Scussel & Federal University of Santa Catarina & Brazil & Relationship Marketing and Consumption Experience \\
\hline & Gisela Demo & University of Brasília & Brazil & Organizational Psychology and Relationship Marketing \\
\hline & Seunghwan Lee & University of Missouri & United States & Hospitality Management \\
\hline \multirow{6}{*}{4} & Dae-Young Kim & University of Missouri & United States & Hospitality Management \\
\hline & Fiona Lettice & University of East Anglia & United Kingdom & Social media and Branding \\
\hline & $\begin{array}{c}\text { Jony Oktavian } \\
\text { Haryanto }\end{array}$ & President University & Indonesia & Consumer Behavior and Marketing Management \\
\hline & José Rojas-Méndez & Carleton University & Canada & Consumer Behavior and International Marketing \\
\hline & Luiz Moutinho & University of Suffolk & United Kingdom & Strategic Marketing \\
\hline & Richard Rutter & Australian College & Kwait & Marketing and Branding \\
\hline
\end{tabular}

review. Firstly, we identified the most productive researchers, as Table 6 shows.

The results from Table 6 enables us to say that the research on brand personality is pulverized, conforming a topic of interest of different scholars in different institutions all over the world. However, when we analyze the area of expertise of the main the marketing and consumer behavior studies, reinforcing the link between brand personality and superior competitive advantage through branding strategies (Kim \& Sung, 2013; Naresh, 2012). Despite the global interest, we did not identify any research network or global research group, a finding that converges with the fact that brand personality is associated with the cultural context of the investigation (Aaker, 1997).

In the following, we explore the most cited articles in the period analyzed and, consequently, the most cited researchers.

The most cited article was Brand personality and culture: The role of cultural differences on the impact of brand personality perceptions on tourists' visit intentions, written by Matzler et al. (2016), with the main objective of investigating the relationships among nation brand personality perceptions. This work explored how cultural differences affect the perception of brand personality in the tourism and hospitality industry, addressing the role of brand personality in building positive associations in consumers' minds. The authors used the theoretical framework of self-congruity to draw their conclusions, indicating the connection between psychology studies and competitive strategies.

The second most cited paper was Advertising content and consumer engagement on social media: Evidence from Facebook. Lee et al. (2018) investigated the role of brand personality in consumer engagement in the context of social media, concluding that when users perceive brand personality of a company in the online scenario, the higher is the engagement. We understand the relevance not only of this paper, but the content combining brand personality and social media, as these networks provide a fertile environment for brands to interact with consumers in a faster and more dynamic way, being brand personality an important aspect to call consumers' attention and connect with the public.

In third place, the article Achieving tourist loyalty through destination personality, satisfaction, and identification reinforces the interest of tourism and hospitality scholars in the brand personality construct. In this study, Hultman et al. (2015) address the impact of brand personality in relational constructs such as word of mouth, satisfaction and revisit intention, proving there is a strong association between brand personality and consumer loyalty.

The fourth most cited paper (Brand management in higher education: The University Brand Personality Scale) and the fifth place (Dimensions of Luxury Brand Personality: Scale Development and researchers, we see observe the importance of brand personality in 
Validation) show the importance of validating the original scale proposed by Aaker (1997) to different contexts, respecting the particularities not only of the culture, but the economic sector of the investigation. These articles reinforce the idea of brand personality as a relational construct, as it serves to build the impression consumers have about a brand and to foster the interest in future transactions.

Our last action in this systematic review was to build a representation of the intellectual structure of the brand personality scientific field. To do so, we performed a bibliographic coupling, a bibliometric method that connects articles based on the number of shared references (Zupic \& Carter, 2015). A citation in the bibliographic reference made by more than one of the articles in the sample, becomes a node in the bibliometric network. The VOS Viewer algorithm uses mapping technique that maximizes the similarity between the nodes, from the reduction of the Euclidean distance, thus forming the clusters (van Eck, Waltman, Dekker, \& van den Berg, 2010). The authors explain that this method does not use the number of citations, covering all the publications in the field, revealing the connections between publications and, from this, emerging topics and subfields. Besides, Zupic and Carter (2015) affirm that bibliometric coupling must be used in limited timeframe, being useful to map up to a five-year interval. From this, the connections between the articles are indicative of similar interests, suggesting brand personality research streams.

In order to label the clusters, we analyzed individually each cluster, examining its articles based on the title, keywords and abstract. Our purpose in this phase was to find the similar content between them, revealing the main thematic of the cluster. Figure 2 illustrates the network obtained. towards brands, the attitude fostered by social media perceptions and the interactions with brands. Thus, we decided to name this stream of research of brand personality and consumer-related outcomes. In this sense, Guido and Peluso (2015) conceptualized brands anthropomorphism observing contour, physiognomy and the way of this product reflects on consumers. Lieven, Grohmann, Herrmann, Landwehr, and van Tilburg (2015) studied the impact of elements such as: logo shape, brand name, font type and color on gender perceptions, consumer preference and brand value. Killian and McManus (2015), on the other hand, sought to understand the impact of social media as a resource for interaction between consumers and organizations, as well as to understand the impact of this tool in building the personality of the brands. The purple cluster is representative of a connection between the blue and the red clusters. The purple cluster includes developments regarding brand personality scales.

The green cluster is dedicated to brand personality in institutional contexts, with three main articles focused on how university students perceive the personality of the institutional brand (Rauschnabel, Krey, Babin, \& Ivens, 2016), the identification between the university and the students (Balaji, Roy, \& Sadeque, 2016) and the similarities between college institutions in the United Kingdom (Rutter, Lettice, \& Nadeau, 2017).

The yellow cluster covers articles about brand personality in the tourism and hospitality industry. In this perspective, Guiry and Vequist (2015) studied medical tourism in South Korea, Liu, Huang, Hallak and Liang (2016) explored the perception of tourists about the Chinese real estate market; and Matzler, Strobl, Stokburger-Sauer, Bobovnicky and Bauer (2016) investigated the intention to visit a tourist destination, starting from individual

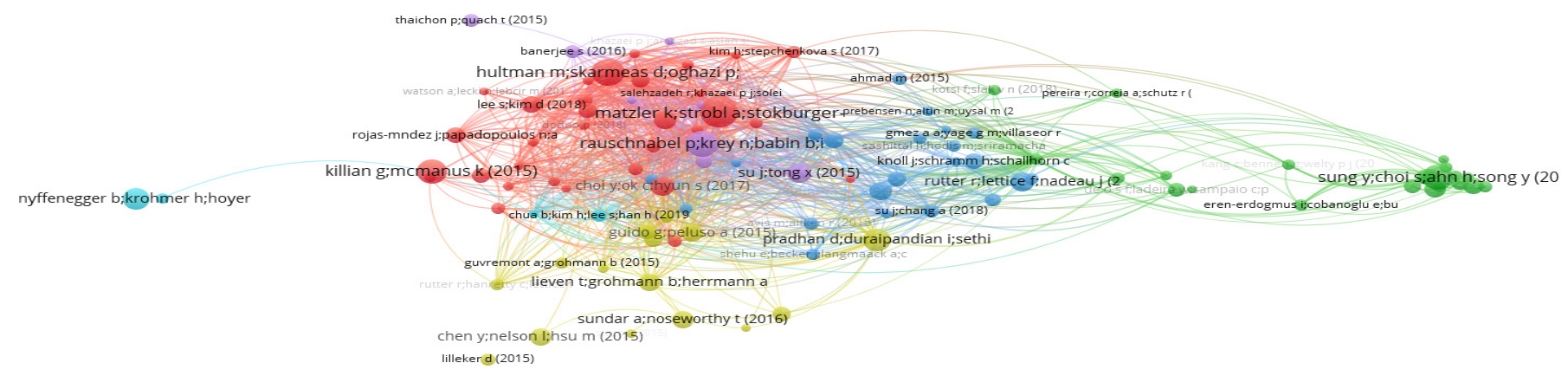

Figure 2. Brand personality bibliographic coupling.

The blue cluster represents the studies focused on brand personality and brand-related outcomes, encompassing works on the relation between brand personality and experience, satisfaction, trust and loyalty. In this perspective, Pradhan, Duraipandian e Sethi (2014) analyzed the relation between brand personality and purchase intention of Indian luxury consumers, and Lunardo, Gergaud e Livat (2015) tested how brand personality of celebrities affects their commercial appeal. Banerjee (2016) points out that the relationship between consumer personality and brand personality has been studied a lot recently, however, given the strong competitiveness, the corporate personality is considered fundamental for the success of organizations. They also state that a good combination of the brand personality with the corporate personality can influence the consumer's brand preference. The findings from this cluster also indicate brand personality has a strong connection with relational outcomes, proving the thesis that brand personality is a driver of long-term relationships between brands and consumers (Fournier, 1998; Scussel \& Demo, 2019).

The red cluster covers the investigations about the impact of brand personality in attitudinal constructs, such as attitude aspects of the perception of brand personality and the desire to avoid risks.

The light blue cluster encompasses studies focused on the use of experiments and metrics to access and comprehend the role of brand personality in consumers' neurological activities, an attempt to comprehend the information processes in consumers' minds. These studies looked at consumers of banking services (Ong, Nguyen, \& Syed Alwi, 2017) and the link between quality and retaining consumers and marketing communication models swap to brand management (Thaichon \& Quach, 2015). The light blue cluster is very close to the red cluster, which can be interpreted as an important aspect to further comprehend the influence of brand personality in consumers' attitudinal responses.

\section{Discussion and Research Agenda Proposition}

The current research on brand personality has a background in psychology studies, with the appropriation of personality construct in order to understand the functioning of consumers' minds, as positive connections between consumers and brands 
are the ultimate goal of marketing research and practice, particularly regarding their role in creating competitive advantage. Nevertheless, as proposed by Paul and Criado (2020), beyond covering the past and analyzing the current research on a scientific field, literature reviews must present detailed and specific guidance for future research, being this the main contribution of a review article. Thus, in order to draw an itinerary for future investigations, we used the analysis of the current research to identify gaps and trends, which has enables us to propose directions for further research.

First, we address the need of theoretical developments on brand personality, especially to understand the evolution of the concept since the seminal article of Aaker (1997) and the global reach of this concept.

Next, based on the strong commitment of scholars in understanding the impact of culture in brand personality, we recommend studies considering the role of culture, addressing comparison between countries in the context of global brands and the perceptions of their brand personality in different scenarios. This interpretation is connected to the major interest in tourism and hospitality literature in brand personality, reinforcing the idea that brand personality is a driver of destination competitiveness.

Additionally, we suggest the investigation of brand personality in emergent countries, due to the need of understanding the imaginary of consumers in countries such as those part of the BRIC - Brazil, Russia, India and China (Scussel \& Demo, 2019). We also foresee the need of addressing the influence of other variables such as gender, sexual orientation, education and social class in the perception on brand personality, which could be a relevant result for brands to understand how different types of consumers perceive brand personality with the purpose of directing their branding strategies to the public.

We also foresee the need of exploring the antecedents of brand personality. Our systematic review has confirmed the role of brand personality as an important driver of many marketing and consumer behavior variables, showing that we have mapped the consequents of brand personality. However, little is known about the drivers of brand personality, in other words, the antecedents of brand personality. Aaker (1997) was the one to propose that brand personality is formed differently than human personality: while human personality is generated in the combination of a person's behavior, physical characteristics, attitudes and beliefs, the brand personality arises from any direct or indirect contact a consumer has with a brand.

In this sense, we suggest scholars to investigate what are these direct or indirect contacts, shedding light into the mechanisms that help consumers to evaluate the personality of a brand. We believe that mixing marketing, psychology and neuroscience would be fruitful to these purposes, context in which experimental studies would be contributive. Besides, as brand personality has a connection with the way consumers perceive a brand (Aaker, 1997), we advise researchers to explore the effect of the organizational context on brand personality, considering the role of organizational culture, product category, service level, online presence and the behavior of employees and sales force.

Besides understanding the antecedents and consequents of brand personality, we believe the stability of brand personality should be investigated. We shed light into the role of time and changes in the consumer behavior and the possible transformations of consumers' perception about the personality traits of a particular brand. Additionally, we wonder if changes in consumers' lifestyles change their perceptions and way of evaluating a brand, and the role of such scenario in the brand personality construct. We also question if possible politic conflicts, organizational behavior or strategic decision of a brand can influence the way consumers see its brand personality.

Lastly, we propose the analysis of brand personality in the context of social media, discussing how brand personality is formed in the digital environment, the relation between online and offline communication of a brand in consumers' perceptions and the role of online interaction in the perception of the personality of a brand.

As a last analysis of the articles in our systematic review sample, we have observed a prevalence of empirical studies based in quantitative methods. In this sense, the use of exploratory and qualitative methods are useful to broaden the knowledge on brand personality. In addition, multi-method studies, combining qualitative and quantitative techniques, including methodological triangulation, are welcome since they provide a greater comprehension of the phenomenon.

From the discussion proposed through this paper, we identified the roots of brand personality is in psychology studies, however, the construct has developed over time and turned into an important consumer behavior concept, in the top of marketing agenda, both in research and practice, due to its association with consumer preference, relational constructs and positive organizational outcomes. In this regard, the analysis of the current panorama on brand personality shows that the future of its research embraces the social and cultural elements of the context of investigation, revealing a connection with not only psychology and strategic marketing, but with sociology and cultural research, which could be an interesting path to deep the knowledge on brand personality.

\section{Conclusion}

The purpose of this paper was to conduct a literature review on the current knowledge in brand personality, an effort to build a research agenda on the construct, setting directions for future investigations. The evaluation of the latest developments on the field showed brand personality is a construct born in psychology and the association of human traits of personality to the context of brands, being a concept explored in marketing research do to its relevance is consumer behavior and branding literature.

In this sense, the studies on brand personality are concentrated in in six major blocks: brand personality and brand-related outcomes; brand personality and consumer-related outcomes; brand personality scales; tourism and hospitality studies; metrics and experiments; and conceptualizations, confirming the strategic role of brand personality in marketing theory and practice. Considering the future of this research, we strongly believe the path started in psychology and developed in marketing must be guided by the social and cultural aspects of the context of investigation.

As limitations of this article, our sample was restricted to only two databases and the last five years of academic production, which means the theme production has not been exhausted. Moreover, we have not included works from conferences, dissertations and thesis. Although our data allowed us to achieve the objective of this paper, we recommend periodic updates of this systematic review in order to track the theoretical and empirical advances in brand personality literature.

Regarding our contributions, we present a review of the latest topics and future trends for brand personality construct, shedding light on what has been done, what is new and the next best thing. This summary works as a guide for scholars, professors, conference chairs and research groups to develop their works based on literature gaps. Besides, the information from this 
article can be used by marketing practioners, brand managers and advertisers to understand the concept of brand personality, its application and possibilities.

\section{References}

Aaker, J. L. (1997). Dimensions of Brand Personality. Journal of Marketing Communications, 34(3), 347-356. https://doi.org/10.1177/00222437970340 $\underline{0304}$

Aaker, J. L., Benet-Martínez, V., \& Garolera, J. (2001). Consumption symbols as carriers of culture: a study of Japanese and Spanish brand personality constructs. Journal of Personality and Social Psychology, 81(3), 492-508. https:// doi.org/10.1037/0022-3514.81.3.492

Azoulay, A. (2005). The malleable personality of brands: the winning facets. Proceedings of the EMAC Colloquium, Milan, Itália, 34.

Balaji, M. S., Roy, S. K., \& Sadeque, S. (2016). Antecedents and consequences of university brand identification. Journal of Business Research, 69(8), 3023-3032. https://doi.org/10.1016/i.jbusres.2016.01.017

Banerjee, S. (2016). Influence of consumer personality, brand personality, and corporate personality on brand preference. Asia Pacific Journal of Marketing and Logistics, 28(2), 198-216. https://doi.org/10.1108/ APJML-05-2015-0073

Choi, Y. G., Ok, C. M., \& Hyun, S. S. (2017). Relationships between brand experiences, personality traits, prestige, relationship quality, and loyalty: An empirical analysis of coffeehouse brands. International Journal of Contemporary Hospitality Management, 29(4), 1185-1202. https://doi.org/10.1108/ IJCHM-11-2014-0601

Demo, G., Silva, T. L. D., Watanabe, E., \& Scussel, F. B. C. (2018). Credibility, audacity and joy: Brand personalities that connect users to social media. Brazilian Administration Review, 15(4), 2-20. https://doi.org/10.1590/18077692bar2018180088

Fournier, S. (1998). Consumers and Their Brands: Developing Relationship Theory in Consumer Research. Journal of Consumer Research, 24(4), 343-373. https://doi.org/10.1086/209515

Freling, T. H., Crosno, J. L., \& Henard, D. H. (2011). Brand personality appeal: conceptualization and empirical validation. Journal of the Academy of Marketing Science, 39(3), 392-406. https://doi.org/10.1007/s11747-010-0208$\underline{3}$

Giroux, M., Pons, F., \& Maltese, L. (2017). The role of perceived brand personality in promotion effectiveness and brand equity development of professional sports teams. International Journal of Sports Marketing and Sponsorship, 18(2), 180-195. https://doi.org/10.1108/IJSMS-05-2017-092

Guido, G., \& Peluso, A. M. (2015). Brand anthropomorphism: Conceptualization, measurement, and impact on brand personality and loyalty. Journal of Brand Management, 22(1), 1-19. https://doi.org/10.1057/bm.2014.40

Guiry, M., \& Vequist, D. G. (2015). South Korea's Medical Tourism Destination Brand Personality and the Influence of Personal Values. Asia Pacific Journal of Tourism Research, 20(5), 563-584.

Hassey, R. V. (2019). How brand personality and failure-type shape consumer forgiveness. Journal of Product \& Brand Management, 28(2), 300-315. https:// doi.org/10.1108/JPBM-09-2017-1563

Huang, H. H., Mitchell, V. W., \& Rosenaum-Elliott, R. (2012). Are consumer and brand personalities the same?. Psychology \& Marketing, 29(5), 334-349. https://doi.org/10.1002/mar.20525

Hultman, M., Skarmeas, D., Oghazi, P., \& Beheshti, H. M. (2015). Achieving tourist loyalty through destination personality, satisfaction, and identification. Journal of Business Research, 68(11), 2227-2231. https://doi. org/10.1016/j.jbusres.2015.06.002

Japutra, A., \& Molinillo, S. (2019). Responsible and active brand personality: On the relationships with brand experience and key relationship constructs. Journal of Business Research, 99, 464-471. https://doi.org/10.1016/j. jbusres.2017.08.027

Keller, K. L. (1993). Conceptualizing, measuring, and managing customer-based brand equity. Journal of Marketing, 57(1), 1-22.

Killian, G., \& McManus, K. (2015). A marketing communications approach for the digital era: Managerial guidelines for social media integration. Business Horizons, 58(5), 539-549. https://doi.org/10.1016/j.bushor.2015.05.006

Kim, D. H., \& Song, D. (2019). Can brand experience shorten consumers' psychological distance toward the brand? The effect of brand experience on consumers' construal level. Journal of Brand Management, 26(3), 255-267. https://doi.org/10.1057/s41262-018-0134-0

Kim, D. H., \& Sung, Y. (2013). Gucci versus Old Navy: Interplay of brand personality and regulatory focus in advertising persuasion. Psychology \& Marketing, 30(12), 1076-1087. https://doi.org/10.1002/mar.20668

Kim, P., Vaidyanathan, R., Chang, H., \& Stoel, L. (2018). Using brand alliances with artists to expand retail brand personality. Journal of Business Research, 85, 424-433. https://doi.org/10.1016/i.jbusres.2017.10.020
Köseoglu, M. A., Okumus, F., Dogan, I. C., \& Law, R. (2019). Intellectual structure of strategic management research in the hospitality management field: A co-citation analysis. International Journal of Hospitality Management, 78 , 234-250. https://doi.org/10.1016/j.ijhm.2018.09.006

Lee, D., Hosanagar, K., \& Nair, H. S. (2018). Advertising content and consumer engagement on social media: Evidence from Facebook. Management Science, 64(11), 5105-5131. https://doi.org/10.1287/mnsc.2017.2902

Lee, Y. I., \& Trim, P. R. (2019). Refining brand strategy: insights into how the "informed poseur" legitimizes purchasing counterfeits. Journal of Brand Management, 26(5), 595-613. https://doi.org/10.1057/s41262-019-00153-x

Lieven, T., Grohmann, B., Herrmann, A., Landwehr, J. R., \& van Tilburg, M. (2015). The effect of brand design on brand gender perceptions and brand preference. European Journal of Marketing, 49, 146-169. https://doi. org/10.1108/EJM-08-2012-0456

Liu, Z., Huang, S., Hallak, R., \& Liang, M. (2016). Chinese consumers' brand personality perceptions of tourism real estate firms. Tourism Management, 52, 310-326. https://doi.org/10.1016/j.tourman.2015.06.022

Lunardo, R., Gergaud, O., \& Livat, F. (2015). Celebrities as human brands: an investigation of the effects of personality and time on celebrities' appeal. Journal of Marketing Management, 31(5-6), 685-712.

Matzler, K., Strobl, A., Stokburger-Sauer, N., Bobovnicky, A., \& Bauer, F. (2016). Brand personality and culture: The role of cultural differences on the impact of brand personality perceptions on tourists' visit intentions. Tourism Management, 52, 507-520. https://doi.org/10.1016/j.tourman.2015.07.017

Muniz, K. M., \& Marchetti, R. Z. (2012). Brand personality dimensions in the Brazilian context. Brazilian Administration Review, 9(2), 168-188. https://doi. org/10.1590/S1807-76922012000200004

Naresh, G. (2012). Do brand personalities make a difference to consumers?. Procedia-Social and Behavioral Sciences, 37, 31-37. https://doi.org/10.1016/i. sbspro.2012.03.272

Nobre, G., Demo, G., Scussel, F., \& Watanabe, E. (2020). The Magical World of Disney: building relationships with clients from the brand personality. Tourism \& Management Studies, 16(1), 39-49. https://doi.org/10.18089/ tms.2020.160104

Okoli, C., \& Schabram, K. (2010). A guide to conducting a systematic literature review of information systems research. Sprouts, 10(26), 1-46.

Omar, M., \& Ensor, J. (2011). Branding in emerging markets. Marketing Intelligence \& Planning, 29(3). https://doi.org/10.1108/mip.2011.02029caa.001

Ong, K. S., Nguyen, B., \& Syed Alwi, S. F. (2017). Consumer-based virtual brand personality (CBVBP), customer satisfaction and brand loyalty in the online banking industry. International Journal of Bank Marketing, 35(3), 370-390. https://doi.org/10.1108/IJBM-04-2016-0054

Paul, J., \& Criado, A. R. (2020). The art of writing literature review: What do we know and what do we need to know?. International Business Review, 29(4), 101717.

Pradhan, D., Duraipandian, I., \& Sethi, D. (2014). Celebrity endorsement: How celebrity-brand-user personality congruence affects brand attitude and purchase intention. Journal of Marketing Communications, 22(3), 1053-1070.

Priporas, C. V., Stylos, N., \& Kamenidou, I. E. (2019). City image, city brand personality and generation $\mathrm{Z}$ residents' life satisfaction under economic crisis: Predictors of city-related social media engagement. Journal of Business Research. https://doi.org/10.1016/i.jbusres.2019.05.019

Radler, V. M. (2017). 20 Years of brand personality: a bibliometric review and research agenda. Journal of Brand Management, 25(4), 370-383. https://doi. org/10.1057/s41262-017-0083-Z

Ramadan, Z. B. (2019). Brand-brand relational moments. Journal of Brand Management, 26(6), 705-716. https://doi.org/10.1057/s41262-019-00163-9

Rather, R. A., Hollebeek, L. D., \& Islam, J. U. (2019). Tourism-based customer engagement: the construct, antecedents, and consequences. The Service Industries Journal, 39(7-8), 519-540. https://doi.org/10.1080/02642069.201 9.1570154

Rauschnabel, P. A., Krey, N., Babin, B. J., \& Ivens, B. S. (2016). Brand management in higher education: the university brand personality scale. Journal of Business Research, 69(8), 3077-3086. https://doi.org/10.1016/j. jbusres.2016.01.023

Rojas-Méndez, J. I., Papadopoulos, N., \& Alwan, M. (2015). Testing self-congruity theory in the context of nation brand personality. Journal of Product \& Brand Management, 24(1), 18-27. https://doi.org/10.1108/JPBM-05-2014-0618

Rutter, R., Lettice, F., \& Nadeau, J. (2017). Brand personality in higher education: anthropomorphized university marketing communications. Journal of Marketing for Higher Education, 27(1), 19-39. https://doi.org/10.1080/08841 241.2016.1213346

Schwarzkopf, S. (2009). Discovering the consumer: Market research, product innovation, and the creation of brand loyalty in Britain and the United States in the interwar years. Journal of Macromarketing, 29(1), 8-20. https:// doi.org/10.1177/0276146708327615 
Scussel, F., \& Demo, G. (2019). The relational aspects of luxury consumption in Brazil: the development of a Luxury Customer Relationship Perception Scale and the analysis of brand personality influence on relationship perception on luxury fashion brands. Brazilian Business Review, 16(2), 174-190. https://doi.org/10.15728/bbr.2019.16.2.5

Snyder, H. (2019). Literature review as a research methodology: An overview and guidelines. Journal of Business Research, 104, 333-339.

Su, J., \& Tong, X. (2015). Brand personality and brand equity: evidence from the sportswear industry. Journal of Product \& Brand Management, 24(2), 124-133. https://doi.org/10.1108/JPBM-01-2014-0482

Sung, Y., Choi, S. M., Ahn, H., \& Song, Y. A. (2015). Dimensions of luxury brand personality: Scale development and validation. Psychology \& Marketing, 32(1), 121-132. https://doi.org/10.1002/mar.20767

Templier, M., \& Paré, G. (2015). A framework for guiding and evaluating literature reviews. Communications of the Association for Information Systems, $37(1), 6$.

Thaichon, P., \& Quach, T. N. (2015). From Marketing Communications to Brand Management: Factors Influencing Relationship Quality and Customer Retention. Journal of Relationship Marketing, 14(3), 197-219. https://doi.org/ $10.1080 / 15332667.2015 .1069523$

Tranfield, D., Denyer, D., \& Smart, P. (2003). Towards a methodology for developing evidence-informed management knowledge by means of systematic review. British Journal of Management, 14(3), 207-222. https://doi. org/10.1111/1467-8551.00375

Unurlu, C., \& Uca, S. (2017). The effect of culture on brand loyalty through brand performance and brand personality. International Journal of Tourism Research, 19(6), 672-681. https://doi.org/10.1002/jtr.2139

Zabkar, V., Arslanagic-Kalajdzic, M., Diamantopoulos, A., \& Florack, A. (2017). Brothers in blood, yet strangers to global brand purchase: A four-country study of the role of consumer personality. Journal of Business Research, 80, 228-235. https://doi.org/10.1016/j.jbusres.2017.06.006

Zupic, I., \& Čater, T. (2015). Bibliometric methods in management and organization. Organizational Research Methods, 18(3), 429-472. https://doi. org/10.1177/1094428114562629

\section{Information about the authors:}

\section{Daniel Carvalho}

Campus Universitário Darcy Ribeiro

70910-900 Brasília, DF, Brasil

E-mail: danizalho@gmail.com

\section{Gisela Demo}

E-mail: giselademo@unb.br

\section{Fernanda Scussel}

E-mail: contatofernandascussel@gmail.com 